\title{
Lower Bmi-1 Expression May Predict Longer Survival of Colon Cancer Patients
}

\author{
Xiaodong Lija,b,c,d Xiao Zheng ${ }^{b, c, d}$ Bin $X^{b, c, d}$ Dachuan Zhang ${ }^{\mathrm{b}}$ Yun Xu $\mathrm{u}^{f}$ \\ Quanqin Xie $^{b}$ Wenwei Hu $u^{a, b, c, d}$ Zhuojun Zheng ${ }^{g}$ Yingjie Shao Jun Wu ${ }^{a}$ Mei Ji ${ }^{a}$ \\ Jingting Jiang ${ }^{b, c, d}$ Changping $\mathrm{Wu}^{\mathrm{a}}$
}

aDepartment of Oncology, The Third Affiliated Hospital of Soochow University, ${ }^{b}$ Department of Biological Treatment, The Third Affiliated Hospital of Soochow University, 'Jiangsu Engineering Research Center for Tumor Immunotherapy, 'Institute of Cell Therapy, Soochow University, eDepartment of Pathology, The Third Affiliated Hospital of Soochow University, 'Department of Gynecology, The Third Affiliated Hospital of Soochow University, ${ }^{9}$ Department of Hematology, The Third Affiliated

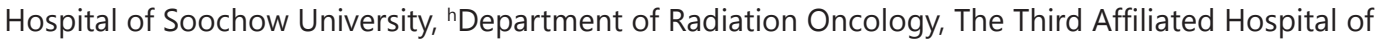
Soochow University, Changzhou, (P. R. China)

\section{Key Words}

Bmi-1 • Colon cancer $•$ Clinical significance $\cdot$ Survival

\begin{abstract}
Background: This study aimed to investigate the Bmi-1 expression and the clinical significance in colon cancer (CC). Patients and Methods: Bmi-1 expression in tumor tissue and the corresponding normal tissue was detected using immunohistological staining. The correlations between Bmi-1 expression and clinicopathological characteristics and the overall survival (OS) time were analyzed. Results: The median $\mathrm{H}$-scores of Bmi-1 in CC tissues and the corresponding tissues were $80.0(0-270)$ and $5.0(0-90)$, with no statistically significant difference $(Z=-13.7, P<0.001)$. Bmi-1 expression in CC tissues was not statistically correlated with any characteristics. The median OS times for CC patients with high or low Bmi-1 expression were 53.7 months and 44.9 months, respectively, with no statistically significant difference $(P$ $=0.123$ ). The survival rates of patients with low Bmi-1 expression were higher than those of patients with high Bmi-1 expression but the differences were not statistically significant. Conclusion: Bmi-1 expression in CC tissue is significantly higher than that in corresponding normal tissue. While there may be a trend towards improved survival, this is not statistically significant.

\section{Introduction}

Colon cancer (CC) is the fourth common malignancy worldwide [1]. In China, both the incidence and mobility rate are increasing recently [2].

X. Li and X. Zheng contributed equally to this work.

Changping Wu and Jingting Jiang

KARGER
Department of Oncology, and Department of Biological Treatment, The Third Affiliated Hospital of Soochow University, 185 Juqian Street, Changzhou, Jiangsu Province (P. R. China); E-Mail wcpjjt@163.com / jiangjingting@suda.edu.cn 


\section{Cellular Physiology Cell Physiol Biochem 2016;39:2421-2426 \begin{tabular}{l|l|l} 
DOI: 10.1159/000452510 & $\begin{array}{l}\text { O 2016 The Author(s). Published by S. Karger AG, Basel } \\
\text { www.karger.com/cpb }\end{array}$
\end{tabular} \\ Li et al.: Bmi-1 in Colon Cancer}

Bmi-1 is a member of the polycomb group which functions as a transcriptional repressor [3, 4]. Bmi-1 gene is associated with tumor invasion and metastasis [5]. Several lines of evidence suggest that Bmi-1 blocks cell senescence and proliferation [6, 7]. Aberrant expression of Bmi-1 has been detected in colorectal carcinoma, breast carcinoma, prostate cancer, liver carcinoma, medulloblastoma, lymphoma, acute myeloid leukemia, head and neck squamous cell carcinoma, non-small cell lung cancer and glioblastoma [5, 6, 8-13]. Bmi1 has been identified as a predictor of the response to therapy and poor survival of patients with various tumors [14-16].

Bmi-1 has been detected in colorectal cancer tissue [17-20] but with smaller sample sizes. In this study, we investigated the expression of Bmi-1 in CC using a larger sample size of tumor tissue and analyzed the correlation between Bmi-1 expression and clinical significance and outcome. We aimed to confirm the potential role of Bmi-1 as a biomarker for the prognosis of CC.

\section{Patients and Methods}

\section{Patients and samples}

This study was approved by the Ethics Committee of The Third Affiliated Hospital of Soochow University (also named The First People's Hospital of Changzhou). Human CC high density tissue microarray obtained from Shanghai Outdo Biotech Co. Ltd. contained 267 primary tumor specimens and the corresponding tissue with follow-up information included. The patients' baseline clinicopathological characteristics are listed in Table 1. Some of the patient's information was not available and thus were secluded from the statistical analysis.

Immunohistochemistry (IHC)

IHC analysis of Bmi-1 was performed using a standard streptavidin-biotin-peroxidase complex method described in our previous article [21]. Two pathologists with no knowledge of the patients' information examined the stained sections independently. The Bmi-1 immunostaining densities were assessed according to the $\mathrm{H}$-score method described [22]. H-score $=(\%$ of tumor cells unstained $\times 0)+(\%$ of tumor cells stained weak $\times 1)+(\%$ of tumor cells stained moderate $\times 2)+(\%$ of tumor cells stained strong $\times 3)$. The H-scores ranged from 0 (100\% negative tumor cells) to 300 (100\% strong staining tumor cells). Results from the two pathologists were averaged and used for statistical analysis.

\section{Statistical analysis}

All data were analyzed with SPSS statistical software (SPSS Standard version 13.0, SPSS Inc.). The Bmi-1 expression between tumor and the corresponding tissues were compared with the Wilcoxon test. The association between Bmi-1 expression and the clinicalpathological characteristics was assessed with the chi-square test. For univariate survival analysis, all CC patients were analyzed by Kaplan-Meier analysis. The log-rank test was used for comparing different survival curves. A $P$ value less than 0.05 was considered statistically significant. Data were expressed as mean \pm standard error.

\section{Results}

Patient baseline characteristics

Table 1 summarizes the patients' available clinicalpathological characteristics. There were 127 male and 140 female cases. There were 17 cases with stage I, 132 with stage II, 107 with stage III and 9 with stage IV.

Correlation between Bmi-1 expression and patient' clinicopathological characteristics

Immunoreactivity for Bmi-1 protein was observed as brown, granular staining on the cell nuclei of tumor cells (Fig. 1). The cut-off value of Bmi-1 expression was 135. The median $\mathrm{H}$-scores of Bmi-1 in CC tissues and the corresponding tissues were $80.0(0-270)$ and $5.0(0-$ 


\section{Cellular Physiology and Biochemistry}

Cell Physiol Biochem 2016;39:2421-2426

\begin{tabular}{l|l}
\hline DOI: 10.1159/000452510 & (C) 2016 The Author(s). Published by S. Karger AG, Basel
\end{tabular}

Published online: November 11, 2016
90), with no statistically significant difference $(Z=-13.7$, $P<0.001)$.

Univariate analysis revealed that there was no statistically significant difference between Bmi-1 expression level and any clinicopathological characteristics (including age, gender, pathological differentiation degree, tumor size, lymph node involvement status, distant metastasis status and TNM stage, all $P>0.05$ ). See Table 1.

Correlation between Bmi-1 expression and the overall survival (OS) time and survival rates

Based on the KaplanMeier survival analysis, cumulative survival curves were calculated, and differences in survival time were assessed with the log-rank test. The median OS times for CC patients with high or low Bmi-1 expression were 53.7 months and 44.9 months, respectively $(P=$ 0.123). See Figure 2.

Table 2 summaries the 1-year to 5-year of CC patients. For patients with high Bim-1 expression ( $\mathrm{n}=74$ ), the 1-year to 5-year survival rates were $75.7 \%, 67.6 \%$, $59.5 \%, 50.3 \%$ and $46.3 \%$, respectively. For patients with low Bim-1 expression $(\mathrm{n}=193)$, the 1-year to 5 -year survival rates were $81.3 \%, 72.5 \%, 66.8 \%, 61.1 \%$ and $56.5 \%$, respectively. We found that the survival rates of patients with low Bmi-1 expression were higher that of patients with high Bmi-1 expression but none of the differences of various years were statistically significant $(P>0.05)$. See Table 2 .
Table 1. Correlation between patient clinicopathological characteristics and Bmi-1 expression. "Tumor size was defined as the largest diameter of the tumor mass

\begin{tabular}{lllllll}
\hline \multirow{2}{*}{ Characteristics } & \multicolumn{7}{c}{ Bmi-1 expression } & \multirow{2}{*}{ Lower } & \multicolumn{2}{l}{ Higher } & \multirow{2}{*}{$\chi^{2}$} & $P$ \\
& No. & $\%$ & No. & $\%$ & & \\
\hline Age & & & & & 4.476 & 0.107 \\
$\leq 60$ & 42 & 82.4 & 9 & 17.6 & & \\
$>60$ and $\leq 70$ & 75 & 72.8 & 28 & 27.2 & & \\
$>70$ & 73 & 66.4 & 37 & 33.6 & & \\
Gender & & & & & 0.588 & 0.443 \\
Female & 89 & 70.1 & 38 & 29.9 & & \\
Male & 104 & 74.3 & 36 & 25.7 & & \\
Pathological differentiation & & & & & 0.572 & 0.751 \\
I & 13 & 68.4 & 6 & 31.6 & & \\
II & 122 & 71.3 & 49 & 28.7 & & \\
$\quad$ III & 58 & 75.3 & 19 & 24.7 & & \\
Tumor size \# & & & & & 1.195 & 0.274 \\
$\leq 5 \mathrm{~cm}$ & 113 & 74.3 & 39 & 25.7 & & \\
$>$ 5cm & 75 & 68.2 & 35 & 31.8 & & \\
Lymph node involvement & & & & & 0.079 & 0.779 \\
No & 106 & 71.1 & 43 & 28.9 & & \\
$\quad$ Yes & 80 & 72.7 & 30 & 27.3 & & \\
Distant metastasis & & & & & 1.295 & 0.255 \\
No & 184 & 71.6 & 73 & 28.4 & & \\
$\quad$ Yes & 8 & 88.9 & 1 & 11.1 & & \\
TNM staging & & & & & 1.724 & 0.632 \\
I & 11 & 64.7 & 6 & 35.3 & & \\
II $\quad$ III & 95 & 72.0 & 37 & 28.0 & & \\
IV & 77 & 72.0 & 30 & 28.0 & & \\
\hline
\end{tabular}

A

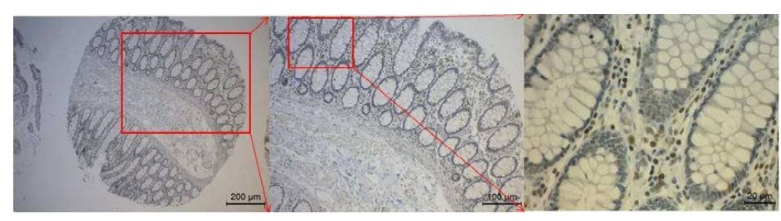

B

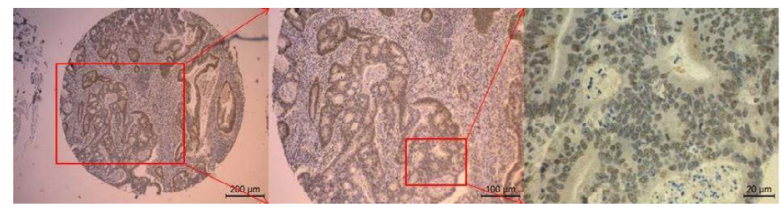

C.

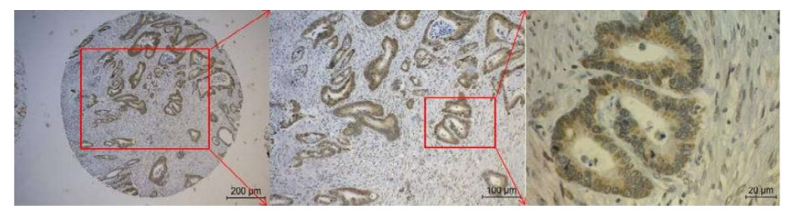

D

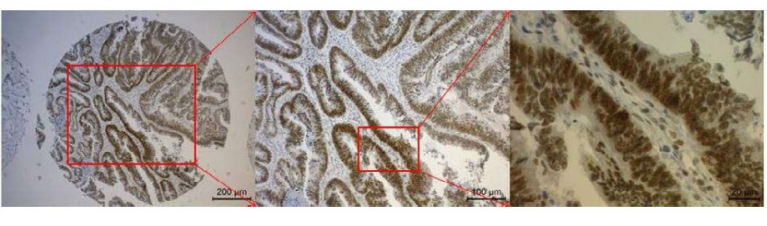

Fig. 1. Immunohistochemical analysis of Bmi-1 showing representative images negative (A) staining in the corresponding tissues and weak (B), moderate (C) and strong (D) staining and in the tumor cells of colon cancer. Bmi-1 protein is observed as brown, granular staining on the cell nuclei of tumor cells. 


\section{Cellular Physiology Cell Physiol Biochem 2016;39:2421-2426

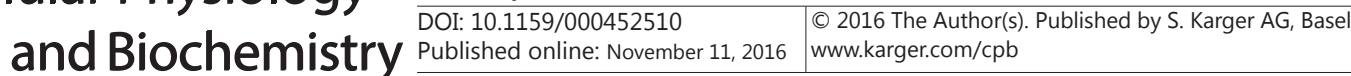 \\ Li et al.: Bmi-1 in Colon Cancer}

Table 2. Association between Bim-1 expression and survival rates of patients with colon cancer

\begin{tabular}{llllll}
\hline Bmi-1 expression $(\mathrm{n})$ & 1 year (\%) & 2 year (\%) & 3 year $(\%)$ & 4 year $(\%)$ & 5 year (\%) \\
\hline Higher (74) & 75.7 & 67.6 & 59.5 & 50.3 & 46.3 \\
Lower (193) & 81.3 & 72.5 & 66.8 & 61.1 & 56.5 \\
\hline
\end{tabular}

Fig. 2. Survival curves of colon cancer patients with high and low Bmi-1 expression levels. There is no statistically significant difference between the overall survival times of the two groups of patients $(P=$ $0.123)$.

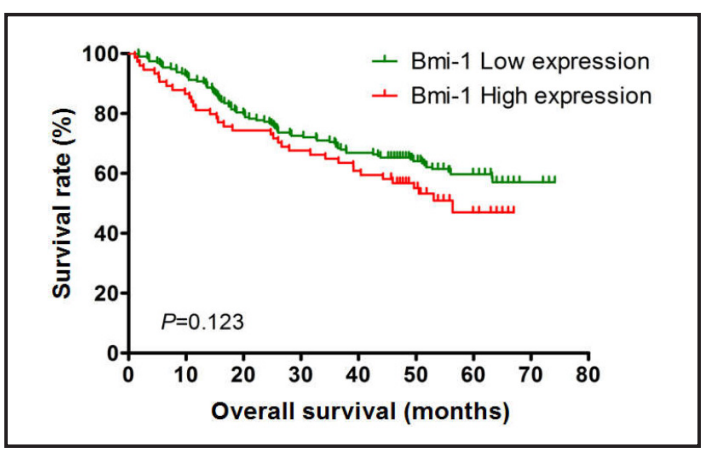

\section{Discussion}

In the present study, we found that the OS of patients with low Bmi-1 expression tended to be longer, however not significant

Other investigators also find that low Bmi-1 expression had a better survival outcome $[20,23]$. And Bmi-1 immunoreactivity emerged as an independent prognostic factor [19]. In pancreatic cancer [4], patients with low Bmi-1 expression had a better survival outcome. We have meta-analyzed the association between Bmi-1 expression and the clinicopathological characteristics and prognosis of patients with various malignancies [24]. The results suggest that high Bmi-1 expression predict poorer clinical outcome.

However, Espersen et al. observed Bmi-1 expression in primary tumors of stage II colon cancer patients could not predict relapse or OS of the patients, thus having a limited prognostic value in stage II colon cancer patients [25]. Furthermore, some other studies suggest opposite conclusions to ours. In breast cancer, patients with high levels of Bmi-1 have a more favorable outcome than patients with low expression of Bmi-1 [26]. And we recently found that high levels of Bmi-1 in gastric cancer patients are significantly associated with better OS $(P=0.02)$ [21].

The differences among the results of various studies might be explained by the complex function of polycomb protein Bmi-1. Bmi-1 functions as a double edged sword. It has been reported that leukemic stem cells lacking Bmi-1 do not proliferate [27, 28]. Bmi-1 protein might be involved in human colorectal carcinogenesis [17]. Bmi-1 is required for colon cancer proliferation in vitro and in vivo [29]. Downregulation of Bmi-1 inhibits cell proliferation and cycle progression and promotes apoptosis of tumor cells of colorectal cancer [30].

Chemoresistance can be facilitated via the upregulation of Bmi-1 [31]. Reducing Bmi-1 expression can inhibit the proliferation of tumor cells and inverse chemoresistance [32]. Meanwhile, tumor cells with high Bmi-1 expression proliferate faster and hence are more sensitive to chemotherapy, leading to longer survival.

Furthermore, our sample size is larger than other studies, although the size alone does not explain the difference of results. Majority of our patient population has stage II and III disease, the omission of stage I and IV patients may alter the results. Besides, some information is unavailable so it is not certain how treatment modalities influence survival. Treatment effect on outcome and clinical follow up for recurrences will further strengthen the findings. This may also be a reason why there is no significant difference in the OS times between the two groups of patients.

Conclusively, while there may be a trend towards improved survival, this is not statistically significant. 


\section{Cellular Physiology Cell Physiol Biochem 2016;39:2421-2426

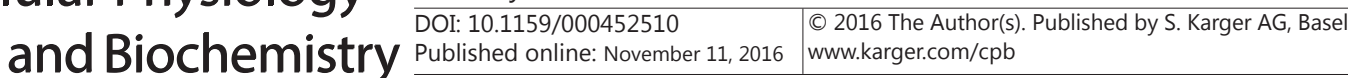 \\ Li et al.: Bmi-1 in Colon Cancer}

\section{Acknowledgements}

This work was supported by grants from National Natural Science Foundation of China (No. 31570877 and 31570908), Jiangsu Engineering Research Center for Tumor Immunotherapy (BM2014404), and Society development plans, Department of Science and Technology Changzhou (CJ20159018).

\section{Disclosure Statement}

The authors declare that they have no conflict of interest.

\section{References}

1 Siegel R, Desantis C, Jemal A: Colorectal cancer statistics, 2014. CA Cancer J Clin 2014;64:104-117.

2 Chen W: Cancer statistics: Updated cancer burden in china. Chin J Cancer Res 2015;27:1.

3 Yin T, Wei H, Leng Z, Yang Z, Gou S, Wu H, Zhao G, Hu X, Wang C: Bmi-1 promotes the chemoresistance, invasion and tumorigenesis of pancreatic cancer cells. Chemotherapy 2011;57:488-496.

4 Guo S, Xu X, Tang Y, Zhang C, Li J, Ouyang Y, Ju J, Bie P, Wang H: Mir-15a inhibits cell proliferation and epithelial to mesenchymal transition in pancreatic ductal adenocarcinoma by down-regulating bmi-1 expression. Cancer Lett 2014;344:40-46.

5 Guo BH, Feng Y, Zhang R, Xu LH, Li MZ, Kung HF, Song LB, Zeng MS: Bmi-1 promotes invasion and metastasis, and its elevated expression is correlated with an advanced stage of breast cancer. Mol Cancer 2011;10:10.

6 Jacobs JJ, Kieboom K, Marino S, DePinho RA, van Lohuizen M: The oncogene and polycomb-group gene bmi-1 regulates cell proliferation and senescence through the ink4a locus. Nature 1999;397:164-168.

7 Wang Y, Guan Y, Wang F, Huang A, Wang S, Zhang YA: Bmi-1 regulates self-renewal, proliferation and senescence of human fetal neural stem cells in vitro. Neurosci Lett 2010;476:74-78.

8 Dimri GP, Martinez JL, Jacobs JJ, Keblusek P, Itahana K, Van Lohuizen M, Campisi J, Wazer DE, Band V: The bmi-1 oncogene induces telomerase activity and immortalizes human mammary epithelial cells. Cancer Res 2002;62:4736-4745.

9 van Lohuizen M, Verbeek S, Scheijen B, Wientjens E, van der Gulden H, Berns A: Identification of cooperating oncogenes in e mu-myc transgenic mice by provirus tagging. Cell 1991;65:737-752.

10 Simon JA, Kingston RE: Mechanisms of polycomb gene silencing: Knowns and unknowns. Nat Rev Mol Cell Biol 2009;10:697-708.

11 Jacobs JJ, Scheijen B, Voncken JW, Kieboom K, Berns A, van Lohuizen M: Bmi-1 collaborates with c-myc in tumorigenesis by inhibiting c-myc-induced apoptosis via ink4a/arf. Genes Dev 1999;13:2678-2690.

12 Wang H, Pan K, Zhang HK, Weng DS, Zhou J, Li JJ, Huang W, Song HF, Chen MS, Xia JC: Increased polycombgroup oncogene bmi-1 expression correlates with poor prognosis in hepatocellular carcinoma. J Cancer Res Clin Oncol 2008;134:535-541.

13 Jiang L, Wu J, Yang Y, Liu L, Song L, Li J, Li M: Bmi-1 promotes the aggressiveness of glioma via activating the nf-kappab/mmp-9 signaling pathway. BMC Cancer 2012;12:406.

14 Silva J, Garcia V, Garcia JM, Pena C, Dominguez G, Diaz R, Lorenzo Y, Hurtado A, Sanchez A, Bonilla F: Circulating bmi-1 mrna as a possible prognostic factor for advanced breast cancer patients. Breast Cancer Res 2007;9:R55.

15 Xin T, Zhang FB, Sui GJ, Jin XM: Bmi-1 sirna inhibited ovarian cancer cell line growth and decreased telomerase activity. Br J Biomed Sci 2012;69:62-66.

16 Wang Y, Zhe H, Ding Z, Gao P, Zhang N, Li G: Cancer stem cell marker bmi-1 expression is associated with basal-like phenotype and poor survival in breast cancer. World J Surg 2012;36:1189-1194.

17 Kim JH, Yoon SY, Kim CN, Joo JH, Moon SK, Choe IS, Choe YK, Kim JW: The bmi-1 oncoprotein is overexpressed in human colorectal cancer and correlates with the reduced p16ink4a/p14arf proteins. Cancer Lett 2004;203:217-224. 


\section{Cellular Physiology Cell Physiol Biochem 2016;39:2421-2426 \begin{tabular}{ll|l} 
DOI: 10.1159/000452510 & $\begin{array}{l}\text { O 2016 The Author(s). Published by S. Karger AG, Basel } \\
\text { www.karger.com/cpb }\end{array}$
\end{tabular} \\ Li et al.: Bmi-1 in Colon Cancer}

18 Liu Y, Yang Y, Xu H, Dong X: Implication of usp22 in the regulation of bmi-1, c-myc, p16ink4a, p14arf, and cyclin d2 expression in primary colorectal carcinomas. Diagn Mol Pathol 2010;19:194-200.

19 Li DW, Tang HM, Fan JW, Yan DW, Zhou CZ, Li SX, Wang XL, Peng ZH: Expression level of bmi-1 oncoprotein is associated with progression and prognosis in colon cancer. J Cancer Res Clin Oncol 2010;136:997-1006.

20 Du J, Li Y, Li J, Zheng J: Polycomb group protein bmi1 expression in colon cancers predicts the survival. Med Oncol 2010;27:1273-1276.

21 Wu C, Zheng X, Li X, Fesler A, Hu W, Chen L, Xu B, Wang Q, Tong A, Burke S, Ju J, Jiang J: Reduction of gastric cancer proliferation and invasion by mir-15a mediated suppression of bmi-1 translation. Oncotarget 2016;7:14522-14536.

22 Zhou Y, Xu Y, Chen L, Xu B, Wu C, Jiang J: B7-h6 expression correlates with cancer progression and patient's survival in human ovarian cancer. Int J Clin Exp Pathol 2015;8:9428-9433.

23 Kreso A, van Galen P, Pedley NM, Lima-Fernandes E, Frelin C, Davis T, Cao L, Baiazitov R, Du W, Sydorenko N, Moon YC, Gibson L, Wang Y, Leung C, Iscove NN, Arrowsmith CH, Szentgyorgyi E, Gallinger S, Dick JE, O'Brien CA: Self-renewal as a therapeutic target in human colorectal cancer. Nat Med 2014;20:29-36.

24 Shao Y, Geng Y, Gu W, Ning Z, Jiang J, Pei H: Prognostic role of high bmi-1 expression in asian and caucasian patients with solid tumors: A meta-analysis. Biomed Pharmacother 2014;68:969-977.

25 Espersen ML, Linnemann D, Christensen IJ, Alamili M, Troelsen JT, Hogdall E: The prognostic value of polycomb group protein b-cell-specific moloney murine leukemia virus insertion site 1 in stage ii colon cancer patients. APMIS 2016;124:541-546.

26 Choi YJ, Choi YL, Cho EY, Shin YK, Sung KW, Hwang YK, Lee SJ, Kong G, Lee JE, Kim JS, Kim JH, Yang JH, Nam SJ: Expression of bmi-1 protein in tumor tissues is associated with favorable prognosis in breast cancer patients. Breast Cancer Res Treat 2009;113:83-93.

27 Park IK, Qian D, Kiel M, Becker MW, Pihalja M, Weissman IL, Morrison SJ, Clarke MF: Bmi-1 is required for maintenance of adult self-renewing haematopoietic stem cells. Nature 2003;423:302-305.

28 He QZ, Luo XZ, Wang K, Zhou Q Ao H, Yang Y, Li SX, Li Y, Zhu HT, Duan T: Isolation and characterization of cancer stem cells from high-grade serous ovarian carcinomas. Cell Physiol Biochem 2014;33:173-184.

29 Yu T, Chen X, Zhang W, Colon D, Shi J, Napier D, Rychahou P, Lu W, Lee EY, Weiss HL, Evers BM, Liu C: Regulation of the potential marker for intestinal cells, bmi1, by beta-catenin and the zinc finger protein klf4: Implications for colon cancer. J Biol Chem 2012;287:3760-3768.

30 He X, Dong Y, Wu CW, Zhao Z, Ng SS, Chan FK, Sung JJ, Yu J: Microrna-218 inhibits cell cycle progression and promotes apoptosis in colon cancer by downregulating bmi1 polycomb ring finger oncogene. Mol Med 2012;18:1491-1498.

31 Lu LL, Chen XH, Zhang G, Liu ZC, Wu N, Wang H, Qi YF, Wang HS, Cai SH, Du J: Ccl21 facilitates chemoresistance and cancer stem cell-like properties of colorectal cancer cells through akt/gsk-3beta/ snail signals. Oxid Med Cell Longev 2016;2016:5874127.

32 Wang E, Bhattacharyya S, Szabolcs A, Rodriguez-Aguayo C, Jennings NB, Lopez-Berestein G, Mukherjee P, Sood AK, Bhattacharya R: Enhancing chemotherapy response with bmi-1 silencing in ovarian cancer. PLoS One 2011;6:e17918. 